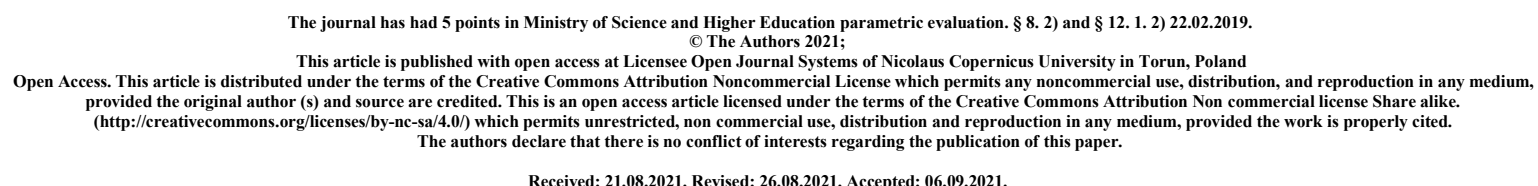

\title{
Awareness of young people from different countries about risk factors influences on cardiovascular diseases
}

Katarzyna Cyboran - katarzyna_cyboran@o2.pl; Medical Faculty, Institute of Medical Sciences, Collegium Medicum, Oleska Street 48, 45-052 Opole Poland

Monika Kuc - kuc.monika96@gmail.com; Medical Faculty, Institute of Medical Sciences, Collegium Medicum, Oleska Street 48, 45-052 Opole Poland

Maria Kalicka - maria.kalicka96@gmail.com; Faculty of Medicine, Medical University of Lublin, Aleje Raclawickie 1 Street, 20-059 Lublin Poland

Tomasz Korzec - tkorzec@poczta.fm; Faculty of Medicine, Medical University of Lublin, Aleje Raclawickie 1 Street, 20-059 Lublin Poland

Konrad Kania - 1konradkania@gmail.com; Faculty of Medicine, Medical University of Lublin, Aleje Raclawickie 1 Street, 20-059 Lublin Poland

\section{ABSTRACT}

One of the main reasons of deaths in the entire world is cardiovascular disease (CVD). Because of this, 17.9 million people died in 2019, which is $32 \%$ of deaths worldwide. Among these deaths, $85 \%$ were due to heart attack and stroke. More than $75 \%$ of deaths occur in lowand middle-income countries. Among the 17 million people under the age of 70 who died prematurely in 2019 due to non-contagious diseases, as many as 38\% were caused by CVD. The most important risk factors for CVD include smoking, an unhealthy diet, obesity, inactivity, and alcohol consumption. These factors reflect the ongoing economic, social, and cultural changes. The development of this disease is also influenced by stress and genetic factors. Thanks to early diagnosis, it is possible to initiate treatment early and increase the patient's chance of survival. [1] 
KEY WORDS: cardiovascular diseases, risk factors, young people

\section{INTRODUCTION AND PURPOSE}

In a situation where the prevention of cardiovascular diseases is introduced in the early stages of childhood, there is a high probability of delaying or eliminating hypertension and its consequences. For this reason, it is important to determine the level of knowledge of young people about cardiovascular diseases. [13]

The aim of this work is to review the literature on the level of knowledge and awareness of adolescents about CVD risk factors.

\section{DESCRIPTION OF THE STATE OF KNOWLEDGE}

Addiction to cigarette smoking is an important problem among adolescents. In a study conducted in Lublin, the authors of which are Opielak $\mathrm{G}$ et al., $41 \%$ of respondents admitted to trying to smoke. In this group, $29 \%$ concern girls, while only $12 \%$ boys. On a positive note, $59 \%$ of students say they have never smoked. At the time of the study, $25 \%$ of adolescents smoked actively, including 15\% regularly. The table shows the opinions of young people about smoking. [2]

\begin{tabular}{|c|c|c|}
\hline Views/gender & Women $(\%)$ & $\operatorname{Men}(\%)$ \\
\hline Accept smoking & 27 & 9 \\
\hline Accept by adults only & 4 & 4 \\
\hline By everyone regardless of age & 3 & 6 \\
\hline By social smokers & 16 & 5 \\
\hline Do not accept & 19 & 7 \\
\hline
\end{tabular}

More and more young people around the world are smoking. It is possible that most of these people do not understand the long-term consequences of this behavior. An interesting project is the WHO framework convention on tobacco control (WHO FCTC). It is the first treaty 
negotiated under the umbrella of the World Health Organization. WHO FCTC was created in response to the globalization of the tobacco epidemic. [3]

A. Steptoe et al. in their study assessed the relationship with the attitude and assessment of tobacco risk awareness in young adults from 21 European countries. As a result of this study, it was found that young people are highly aware of the relationship between smoking and the risk of lung cancer. In the case of awareness of smoking and cardiovascular diseases, the results were much worse. There were significant differences in individual countries. Awareness among men was $64.4 \%$, and among women $62.9 \%$. Moreover, awareness was higher among smokers than among non-smokers. The results show that young Europeans have large gaps in their awareness of smoking. [4]

Recently, the moment of alcohol initiation has been dropping drastically. It gets up to a situation where alcohol becomes an inseparable element of family, social and other gatherings. The effect of the life of young people in the world shaped in such a way is the pursuit of the opportunity to try alcohol. In the later stages, it may promote the development of alcohol dependence.

Smoking and obesity are among the most common causes of premature death in the US. Right behind them is alcohol abuse, which is inextricably linked with an increased risk of cardiovascular disease. It is worth noting that the risk-benefit ratio appears to be higher in young people who also have a higher rate of excessive binge drinking, which translates into an increase in the frequency of intoxication and its consequences. [5]

Matshipi et al. conducted a study on alcohol consumption and knowledge about cardiovascular diseases among adolescents aged 14-22 living in Ellislas (a city in southern Africa). Dissemination of drinking alcohol among girls was worrying as it increased from $13.6 \%$ to $17.7 \%$. The situation is similar for boys, an increase from $10.3 \%$ to $16.9 \%$. The study showed that adolescents were very knowledgeable about CVD risk factors. Nevertheless, it is worth putting more emphasis on educating village Ellisras youth about the risks associated with risk factors for heart and vascular disease, as responses to some of the survey questions that were below expectations. [6]

One of the diseases of civilization is obesity. We can observe it more and more often among younger age groups. The long-term effects of increased body weight in young people include the development of chronic diseases and thus a reduction in the quality of life. [7] Bridger in his work emphasizes that several studies have shown a relationship between childhood obesity and the development of cardiovascular disease in adulthood. Additionally, it has been shown that BMI in childhood has a significant influence on cardiovascular events in adulthood. [8] Moreover, Must A et al. in their work proved that body weight in children is an independent risk factor for CVD. [9] In their study, Zięba et al. note that the incidence of cardiovascular disease is closely related to lifestyle and shows low public awareness of this subject, as well as the need to broaden knowledge. The aim of her work was to find out about 
the knowledge of students of the secondary school of the Nowy Targ district (Poland) on CVD and prevention. It turned out that $70 \%$ of the respondents had mediocre knowledge and $8 \%$ insufficient. Interestingly, at the same time, $41.3 \%$ of students believe that their level of knowledge is sufficient and $29 \%$ of respondents assessed their knowledge as incomplete and requiring supplementation. [10] Summing up, it is worth noting that some programs are necessary to raise the level of knowledge about civilization diseases and their long-term consequences.

An unhealthy diet has a negative effect on cardiovascular diseases. A diet high in unsaturated fatty acids, fiber, and plant-based foods can significantly reduce the risk of heart disease. [11] A balanced diet is important for children and adolescents, in addition to preventing CVD, it also enables proper growth and development. A diet to protect against heart disease includes an appropriate amount of calories to prevent excess weight gain and reduce fat intake. The United States Department of Agriculture pays special attention to saturated fat. [12]

Ostrówka et al. conducted a survey in two selected high schools in the Tri-City agglomeration (Poland) in 2000 and then repeated in 2016. The participants completed a questionnaire in which they answered questions about their knowledge about cardiovascular risk factors and health habits. As a result of this study, they concluded that awareness of the negative effects of high blood pressure and other cardiovascular risk factors has increased over the past 15 years, but is still insufficient. [13]

\section{LIST OF REFERENCES}

1. https://world-heart-federation.org/what-is-cvd/

2. Opielak $\mathrm{G}$, et al. Palenie tytoniu wśród młodzieży szkół średnich w świetle aktualnych badań. Forum Med Rodz. 2014; 8(4): 190-194.

3. Tanski SE, Prokhorov AV, Klein JD. Youth and tobacco. Minerva Pediatr. 2004; 56(6): 553-565, indexed in Pubmed: 15765019.

4. A Steptoe, J Wardle, H Smith, M Kopp, A Skrabski, J Vinck, A M Zotti; Tobacco smoking in young adults from 21 European countries: association with attitudes and risk awareness; Comparative Study Addiction 1995 Apr;90(4):571-82, indexed in Pubmed: 7773120

5. James H O'Keefe, Salman K Bhatti, Ata Bajwa, James J DiNicolantonio, Carl J Lavie; Alcohol and cardiovascular health: the dose makes the poison...or the remedy; rewiev Mayo Clin Proc. 2014 Mar;89(3):382-93. indexed in Pubmed: 24582196

6. Moloko Matshipi,Kotsedi D. Monyeki, Norman Mafumo, Suzan M. Monyeki, Hlengani J. Siweya and Han C. G. Kemper; The Use of Alcohol and Knowledge of Cardiovascular Diseases among Ellisras Rural Children Aged 14-22 Years: Ellisras Longitudinal Study; Int J Environ Res Public Health. 2019 Aug; 16(15): 2650; PMID: 31344981

7. Daria Przybylska, Maria Kurowska, Piotr Przybylski; Obesity and overweight in the adolescent population; Hygeia Public Health 2012, 47(1): 28-35 
8. Tracey Bridger; Childhood obesity and cardiovascular disease; Paediatr Child Health. 2009 Mar; 14(3): 177-182

9. Must A, Jacques PF, Dalla GE i in. Długoterminowa zachorowalność i śmiertelność nastolatków z nadwagą: kontynuacja Harvard Growth Study z 1022 do 1935. N Engl J Med. 1992; 327 : 1350. [ PubMed ] [ Google Scholar ]

10. Zięba M, et al. Wiedza młodzieży szkół ponadgimnazjalnych powiatu nowotarskiego na temat chorób krążenia i ich profilaktyki. Problemy Pielęgniarstwa. 2013; 21(1): 88-97.

11. https://www.betterhealth.vic.gov.au/health/conditionsandtreatments/heart-diseaseand-food

12. https://www.urmc.rochester.edu/encyclopedia/content.aspx? contenttypeid=1\&content id $=4508$

13. Ostrówka D, Jancewicz M, Komand A, et al. Awareness of the role of cardiovascular risk factors and their prevention from the perspective of Tricity adolescents. Arterial Hypertens. 2017; 21(1): 51-59, doi: 10.5603/ah.2017.0007. 